\title{
Changes in soil morphology of Podzols affected by alkaline fly ash blown out from the dumping site of an electric power plant
}

\author{
Jerzy Weber ${ }^{1}$ (D) $\cdot$ Andrzej Kocowicz $^{1} \cdot$ Magdalena Debicka $^{1} \cdot$ Elżbieta Jamroz $^{1}$
}

Received: 31 March 2016 / Accepted: 2 November 2016 / Published online: 12 November 2016

(C) The Author(s) 2016. This article is published with open access at Springerlink.com

\begin{abstract}
Purpose The impacts of fly ash on the chemistry of forest floors were previously described in literature, while impacts on soil properties were less recognised. Soil investigations were focussed mainly on increases of $\mathrm{pH}$ and base saturations in surface horizons. The purpose of this study was to describe the influence of alkaline fly ash blown out from the dumping site of a lignite-fired power plant on $\mathrm{pH}$ changes of ectohumus horizons of Podzols and the morphology of deeper horizons. Materials and methods We investigated the soil profiles of Podzols derived from loose quartz sand and developed under pine forest surrounding the dumping site of the power plant Bełchatów, central Poland. In the vicinity of the fly ash dumping site, five Podzol profiles located at a distance of $50 \mathrm{~m}$ from the dumping site were investigated, as well as soil profiles located along the transect set at distances of 50,300, 800 and $2000 \mathrm{~m}$ from the dumping site. Control profiles were located at a distance of $7.3 \mathrm{~km}$ from the dumping site. Soil morphology was described in the field and the following properties were determined: soil texture, hydrolytic acidity, exchangeable cations, total organic carbon and total nitrogen content.

Results and discussion The $\mathrm{pH}$ values of Podzol ectohumus horizons located close to the dumping site ranged from 6.01 to 7.34 compared to a range of 3.08-3.72 in the control. Ectohumus horizon located $300 \mathrm{~m}$ from the dumping site showed a $\mathrm{pH}$ range of 4.13-4.26, while at a distance of
\end{abstract}

Responsible editor: Jadran Faganeli

Jerzy Weber

jerzyweber@gmail.com

1 Institute of Soil Science and Environmental Protection, Wroclaw University of Environmental and Life Sciences, Grunwaldzka 53, 50-357 Wroclaw, Poland
$800 \mathrm{~m}$, the $\mathrm{pH}$ values did not differ from those of the control site. The upper part of the eluvial soil horizons located close to the dumping site had been transformed into transitional $\mathrm{AE}$ horizons in which humic substances translocated from ectohumus horizons were accumulated. Moreover, the organic carbon content of this horizon increased compared to the carbon content of the illuvial Bs horizon located below it. Under the influence of alkalisation of upper horizons, the illuvial Bhs horizons vanished and were transformed into Bs horizons.

Conclusions Changes in soils affected by fly ashes are connected with alkalinisation of ectohumus horizons. Podzolisation processes can be reduced or even completely stopped regarding the distance from the dumping site. Eluvial Podzol horizons located close to the dumping site may be transformed into AE horizons in which humic substances translocated from ectohumus horizons are accumulated. Due to transformation and translocation of organic components, Bhs horizons can be transformed into Bs horizons.

Keywords Alkalization · Dumping site · Fly ash · Morphology $\cdot$ Podzol $\cdot$ Soil

\section{Introduction}

Anthropogenic factors strongly modify soil properties; thus, their impacts on chemical, physical and biological properties have been reported widely. The acidification of the soil environment has been described for many locations, while the opposite effect - an increase of soil $\mathrm{pH}$ caused by anthropogenic activity - has rarely been studied (Van Breemen et al. 1983; Mandre and Ots 1999; Mandre et al. 2008; Pichler et al. 2009). Alkalisation is a problem frequently associated with the cement industry, limestone quarrying, production of phosphorus compounds and emission of fly ashes. This problem 
appears in many areas, sometimes at a massive scale, and may even cover areas of more than several thousands of square kilometres (Haapala et al. 1996; Mandre and Ots 1999; Haapala et al. 2001; Langer and Gunther 2001; Mandre et al. 2008; Pichler et al. 2009). One of the major emitters of alkaline ashes, which contain hydroxides and $\mathrm{Ca}$ and $\mathrm{Mg}$ carbonates (Haynes 2009; Ahmaruzzaman 2010; Ukwattage et al. 2013; Yao et al. 2014; Weber et al. 2015), is lignite-fired power plant. In many countries, including Poland, the combustion of lignite is still the main source of energy; thus, there is a large amount of generated fly ashes, globally estimated to be 750 million $\mathrm{t}$ annually (Ahmaruzzaman 2010). Almost $70 \%$ of ashes are collected as landfills or on dumping sites (Haynes 2009) from where they may be blown out, contributing to alkalisation of the surrounding environment (Jala and Goyal 2006).

Fly ash impacts on forest vegetation (Mandre and Ots 1999; Ots 2003; Mandre et al. 2008; Zolnierz et al. 2016) and the forest floor chemistry (Klose and Makeshin 2003) were previously described in the literature, while impacts on the mineral part of the soil were less considered. Soil investigations were focussed mainly on $\mathrm{pH}$ changes in surface horizons (Haapala et al. 1996; Klose et al. 2001), physical properties (Hartmann et al. 2010a, b) and solubility of heavy metals (Haapala et al. 2001). Fly ashes emitted by lignitefired power plants affect the surrounding environment, which is clearly marked in the magnetic susceptibility of the ectohumus horizons (Klose et al. 2001) and in significantly higher concentrations of $\mathrm{NH}_{4} \mathrm{Cl}$-extractable cations and increased base saturations (Klose and Makeshin 2003). Submicroscopic investigations of forest soils showed that atmospheric fly ash deposition can be detected and identified only in ectohumus horizons (Klose et al. 2001). Enrichment of some trace elements and decrement in dehydrogenase and phosphatase enzymatic activities in soils in the vicinity of coal-fired power plants were also observed (Raja et al. 2015).

Previous studies have evaluated the effects of artificial liming on podzolisation processes and soil morphology (Bain et al. 2003; Lundström et al. 2003a, b); however, studies on the change of acid soil environments as a result of alkaline fly ash deposition are scarce. This regards especially to Podzols, which indicate specific morphology caused by interaction with strongly acidic forest litter layer (Lundström et al. 2000a, b; Buurman and Jongmans 2005). Under such conditions, podzolisation occurs, in which aluminosilicates are strongly altered and products of weathering together with humic substances are moved down the profile, contributing to establishing specific eluvial (E) and illuvial (Bhs) horizons. Deposition of alkali fly ash affects $\mathrm{pH}$ values of surface layers of the soil, which may increase organic matter solubility and organic matter leaching (Andersson et al. 2000; Andersson and Nilsson 2001; Aciego Pietri and Brookes 2008). This may disturb natural processes of accumulation and translocation of organic components in Podzol profiles;
Fig. 1 Location of the fly ash dumping site of Bełachatów power plant and investigated profiles at a distance of 50, 2000 and $7000 \mathrm{~m}$

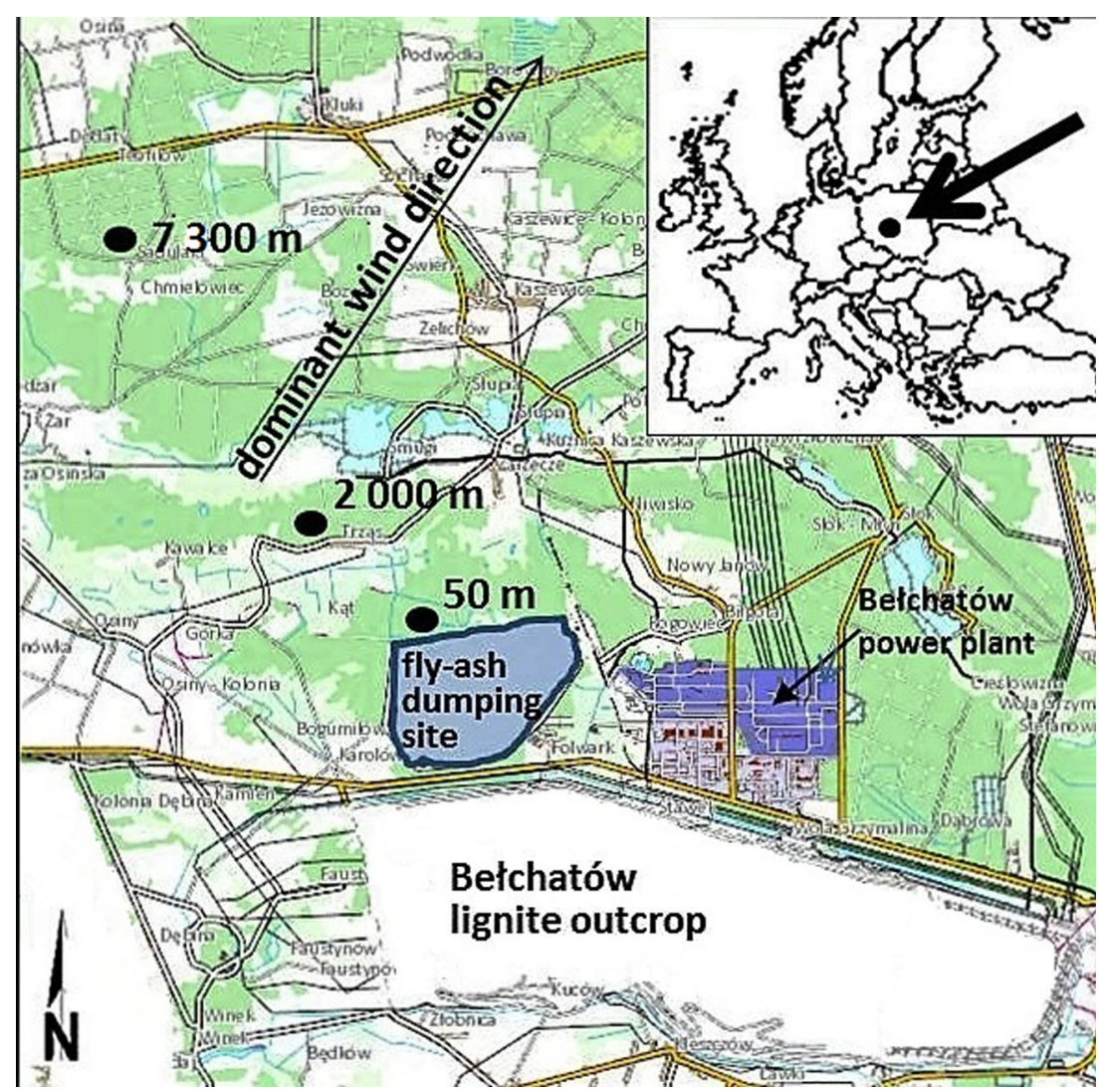


however, these processes are still not sufficiently understood. The aim of this study was to determine changes in morphology of Podzols under the influence of alkaline fly ash deposited in the vicinity of the dumping site of a lignite-fuelled power plant.

\section{Materials and methods}

\subsection{Area and study objects}

The research was conducted in the vicinity of the fly ash dumping site of the power plant Bełchatów, central Poland $\left(51^{\circ} 19.9^{\prime} \mathrm{N} ; 19^{\circ} 12.1^{\prime} \mathrm{E}\right)$. Locations of the dumping site and the electric power plant Bełchatów and the profiles investigated are presented in Fig. 1. The area has an annual rainfall of $609 \mathrm{~mm}$ and an annual average temperature of $9.3{ }^{\circ} \mathrm{C}$. Dominant wind direction is from southwest to northeast.

The dumping site was built in 1981 in order to store fly ash via the hydraulic method (Fig. 2a). It consists of a 40$\mathrm{m}$ high heap with a surface area of 439 ha. The ash consists mainly of silicon, aluminium and iron and is highly alkaline ( $\mathrm{pH}$ above 9), which is due to the high amount of calcium (23-29\% $\mathrm{CaO})$ occurring in oxide and carbonate forms (Ostrowski 2011).
Fig. 2 The surface of the dumping site (a) and the pine forest in the vicinity of the power plant Bełchatów (b)
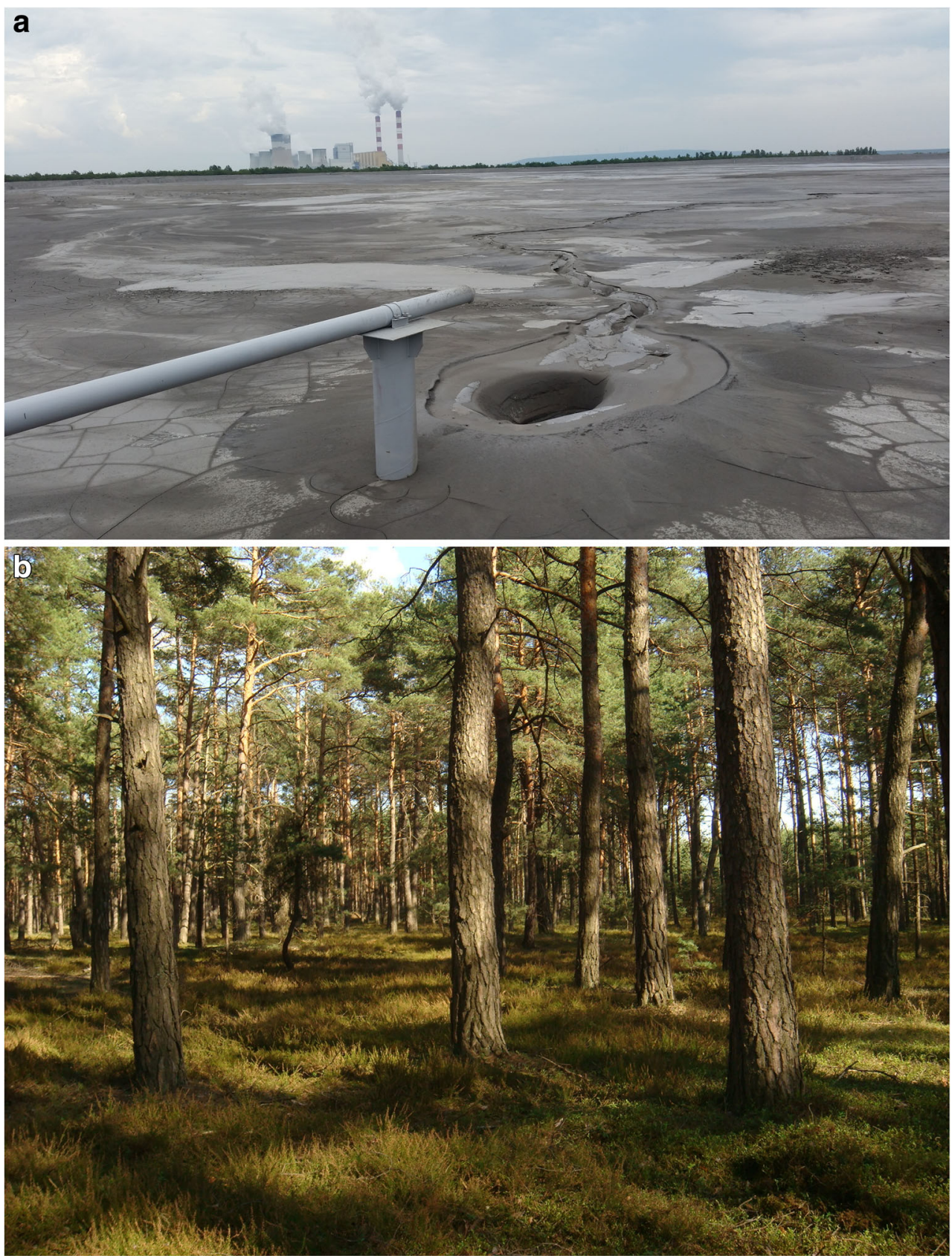
We investigated soil profiles of Podzols derived from loose quartz sand; the soil had developed under pine forest (Fig. 2b) surrounding the dumping site. Control profiles (K1, K2, K3) were located at a distance of $7.3 \mathrm{~km}$ northwest to the dumping site (Fig. 3a, Table 1). In the vicinity of the fly ash dumping site, five Podzol profiles (P1, P2, P3, P4, PN1) within a distance of $50 \mathrm{~m}$ from the dumping site were investigated (Fig. 3b, Table 2), and soil profiles located along the transect set in the northeast direction within a distance of 50 (PN1), 300 (PN2), 800 (PN3) and $2000 \mathrm{~m}$ (PN4) from the dumping site (Table 3).

\subsection{Methods}

Soil profile morphology was described in the field (Guidelines for soil description, FAO 2006), and soil samples were collected from each genetic horizon. The collected material was air-dried and sieved through a 2-mm mesh. The following properties were determined in soil fraction $<2 \mathrm{~mm}$ : soil texture with sedimentation-sieve method according to Bouyoucos, with Casagrande and Prószyński modifications (Gee and Bauder 1986); $\mathrm{pH}$ potentiometrically in $1 \mathrm{M} \mathrm{KCl}$; hydrolytic acidity (HA) using the Kappen method (1 M ammonium acetate); exchangeable cations (EC) using the Pallmann method (ammonium acetate); total organic carbon (TOC) via a CSMAT 5500 analyser (Strohlein $\mathrm{GmbH} \&$ Co., Kaarst, Germany, currently Bruker AXS Inc., Madison, WI, USA); and total nitrogen content $(\mathrm{N})$ by the Kjeldahl method, while cation exchangeable capacity (CEC) and base saturation (BS) were calculated on the basis of the results of HA and EC.

\section{Results}

\subsection{Control profiles}

Control soil profiles were classified as Podzols (FAO-WRB 2014) with a typical soil horizon layout of O-E-Bhs-Bs-C (Table 1). The soil material of all investigated soil profiles, including control and affected soil profiles, indicated similar texture of mineral horizons (Tables 1 and 2), where sand fractions dominate (94-99\%). The share of silt and clay fractions was $0-4 \%$.

All investigated control profiles were strongly acidic, with the lowest $\mathrm{pH}$ values in the Oea litter horizons, ranging from 3.37 to 3.72 . The $\mathrm{pH}$ increased down the profile, reaching a value of 4.35 in the parent material horizon, where the impact of acidic components leaching from the ectohumus horizons was strongly limited. The highly acidic nature of the Podzols was reflected in their cation exchange properties (Table 4). Base saturation in eluvial E horizons ranged from 34 to $36 \%$ and increased in the deeper horizons to $65-84 \%$. In mineral horizons, the highest values of
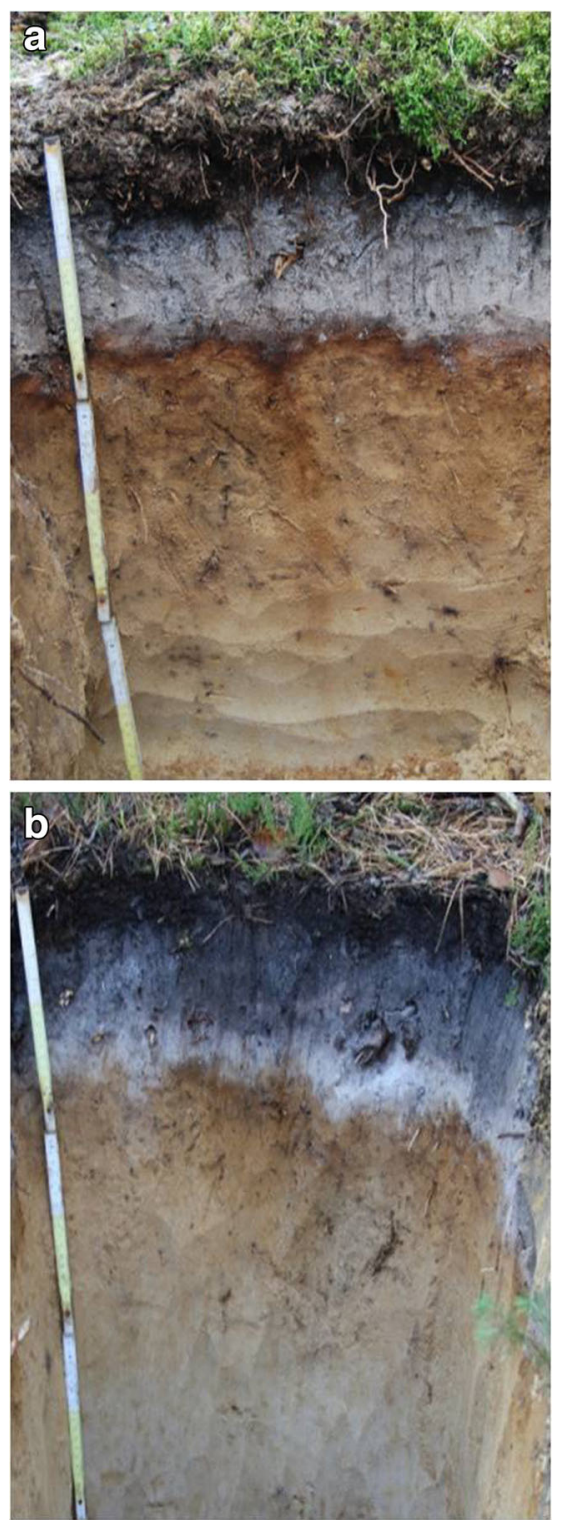

Fig. 3 Podzol K1 profile located $7.3 \mathrm{~km}$ from the dumping site (a) and $\mathrm{P} 2$ profile located $50 \mathrm{~m}$ from the dumping site (b)

the cation exchange capacity and soil acidity were found in Bhs horizons, which were due to the highest organic matter content.

Profile distribution of organic carbon was typical for Podzols. The highest content of organic $\mathrm{C}$ was found in ectohumus $\mathrm{Oi}$ and Oea horizons, which contained large amounts of organic compounds with a low degree of mineralisation. This is demonstrated by a high $\mathrm{C} / \mathrm{N}$ ratio, ranging between 45 and 51 (Table 1). Due to podzolisation, the content of organic $\mathrm{C}$ was very low in E eluvial horizons (4.47-6.14 $\mathrm{g} \mathrm{kg}^{-1}$ ) and much higher in Bhs illuvial horizons (12.36-18.37 $\mathrm{g} \mathrm{kg}^{-1}$ ). Below these horizons, organic $\mathrm{C}$ content was significantly lower $\left(1.36-3.27 \mathrm{~g} \mathrm{~kg}^{-1}\right)$ both in Bs and $\mathrm{C}$ horizons. 
Table 1 Soil morphology, the content of TOC and $\mathrm{N}$ and $\mathrm{pH}$ at a distance of $7.3 \mathrm{~km}$ from the dumping site

\begin{tabular}{|c|c|c|c|c|c|c|c|c|}
\hline Profile & Soil horizon & Thickness (cm) & Colour & TOC $\left(\mathrm{g} \mathrm{kg}^{-1}\right)$ & $\mathrm{N}\left(\mathrm{g} \mathrm{kg}^{-1}\right)$ & $\mathrm{C} / \mathrm{N}$ & $\mathrm{pH}(\mathrm{KCl})$ & Sand $(\%)$ \\
\hline \multirow[t]{6}{*}{ K1 (NW 7.3 km) } & Oi & $0-3$ & 10YR 3/1 & 340.90 & n.d. & n.d. & 3.37 & n.d. \\
\hline & Oea & $3-9$ & 10YR 3/1 & 138.20 & 3.08 & 45 & 3.08 & n.d. \\
\hline & $\mathrm{E}$ & $9-22$ & 10YR 7/1 & 6.14 & 0.20 & 31 & 3.03 & 97 \\
\hline & Bhs & $22-25$ & $10 Y R 4 / 3$ & 12.36 & 0.41 & 30 & 3.89 & 95 \\
\hline & Bs & $25-50$ & 10YR 7/6 & 1.36 & 0.07 & 19 & 4.20 & 94 \\
\hline & $\mathrm{C}$ & $>50$ & 10YR $8 / 2$ & 0.60 & 0.06 & 10 & 4.35 & 97 \\
\hline \multirow[t]{6}{*}{ K2 (NW 7.3 km) } & Oi & $0-4$ & 10YR 3/1 & 421.78 & n.d. & n.d. & 3.72 & n.d. \\
\hline & Oea & $4-10$ & 10YR 3/1 & 156.42 & 3.34 & 47 & 3.62 & n.d. \\
\hline & $\mathrm{E}$ & $10-20$ & 10YR 7/1 & 4.47 & 0.17 & 26 & 3.04 & 96 \\
\hline & Bhs & $20-27$ & $10 \mathrm{YR} 4 / 3$ & 13.79 & 0.76 & 18 & 3.66 & 97 \\
\hline & Bs & $27-50$ & 10YR $7 / 5$ & 2.68 & 0.18 & 14 & 4.21 & 97 \\
\hline & $\mathrm{C}$ & $>50$ & 10YR $8 / 2$ & 0.99 & 0.09 & 11 & 4.26 & 96 \\
\hline \multirow[t]{6}{*}{ K3 (NW 7.3 km) } & Oi & $0-3$ & 10YR $3 / 2$ & 338.10 & n.d. & n.d. & 3.52 & n.d. \\
\hline & Oea & $3-8$ & 10YR 3/1 & 146.60 & 2.87 & 51 & 3.32 & n.d. \\
\hline & $\mathrm{E}$ & $8-21$ & 10YR $7 / 2$ & 5.62 & 0.13 & 43 & 3.06 & 96 \\
\hline & Bhs & $21-32$ & $10 \mathrm{YR} 4 / 3$ & 18.37 & 0.65 & 28 & 3.71 & 97 \\
\hline & Bs & $32-50$ & 10YR $7 / 4$ & 3.27 & 0.10 & 33 & 4.23 & 96 \\
\hline & $\mathrm{C}$ & $>50$ & 10YR $8 / 2$ & 0.94 & 0.04 & 24 & 4.29 & 98 \\
\hline
\end{tabular}

n.d. not determined

\subsection{Soil profiles at a distance of $50 \mathrm{~m}$ from the dumping site}

Soils located close to the dumping site are under its strong alkalescent influence. As a result of fly ash blowing out from the surface of the dumping site, ectohumus horizons showed $\mathrm{pH}$ values as high as 6.01-7.34 (Table 2), which is unique for Podzols. The $\mathrm{pH}$ values decreased gradually with the depth of the soil profiles, but even the deepest $\mathrm{C}$ horizons showed higher $\mathrm{pH}$ values than the corresponding horizons of the control soils. The content of base cations was therefore very high in top horizons and decreased down the profiles. Consequently, mineral horizons showed the highest values of base saturation in AE horizons (75-85\%) and in E eluvial horizons $(38-80 \%)$. The base cations were dominated by $\mathrm{Ca}^{2+}$, whose share in $\mathrm{CEC}$ of $\mathrm{AE}$ and $\mathrm{E}$ horizons reached $51-79 \%$.

Directly below the ectohumus horizons, AE horizons were present, which had been transformed from previously existing E eluvial horizons (Table 2). This concerns mostly the upper parts of the $\mathrm{E}$ horizons, but in some cases, the whole $\mathrm{E}$ horizon had been transformed into $\mathrm{AE}$ (in the P1 profile, no remnants of $\mathrm{E}$ horizon were left). These newly developed horizons differed from the originally existing $\mathrm{E}$ horizons in terms of higher TOC contents (6.57$29.77 \mathrm{~g} \mathrm{~kg}^{-1}$ ) and darker colours (10YR 5/1-10YR 6/1) (Table 2), which was clearly reflected by their morphology (Fig. 3b). The E horizons indicated much lower TOC contents (2.72-6.93 $\mathrm{g} \mathrm{kg}^{-1}$ ); however, organic C contents were, in some cases, higher in these horizons than in the underlying Bs illuvial horizons.

Previously existing Bhs horizons had been transformed into Bs horizons, indicated by the significantly lower TOC contents (3.64-4.77 $\mathrm{g} \mathrm{kg}^{-1}$ ); still existing Bhs horizons (as in P4 and PN1 profiles) clearly showed lower TOC values (Tables 2 and 3). Furthermore, Bhs horizons showed considerably lower thickness values $(1-2 \mathrm{~cm})$.

\subsection{Soil profiles located along the transect 50 to $2000 \mathrm{~m}$ from the dumping site}

The alkalescent influence on properties of Oea horizons in soil profiles located along the transect is distinctly reduced with distance (Table 3). The ectohumus horizons of soil profiles located $300 \mathrm{~m}$ from the dumping site still showed a moderate increase of $\mathrm{pH}$ values (4.26), while in the PN3 profile, located $800 \mathrm{~m}$ from the dumping site, the $\mathrm{pH}$ values were comparable to those of the control profiles (K1, K2, K3). Properties of deeper horizons were also similar to control objects. Profiles at 800 and $2000 \mathrm{~m}$ from the dumping site showed an acidic reaction in all horizons and were morphologically comparable to the controls with well-developed $\mathrm{E}$ eluvial and Bhs illuvial horizons. C contents of these profiles were also similar to the control profiles (even at $300 \mathrm{~m}$ from the dumping site). 
Table 2 Soil morphology, the content of TOC and $\mathrm{N}$ and $\mathrm{pH}$ at a distance of $50 \mathrm{~m}$ from dumping site

\begin{tabular}{|c|c|c|c|c|c|c|c|c|}
\hline Profile & Soil horizon & Thickness (cm) & Colour & TOC $\left(\mathrm{g} \mathrm{kg}^{-1}\right)$ & $\mathrm{N}\left(\mathrm{g} \mathrm{kg}^{-1}\right)$ & $\mathrm{C} / \mathrm{N}$ & $\mathrm{pH}(\mathrm{KCl})$ & Sand $(\%)$ \\
\hline \multirow[t]{6}{*}{$\mathrm{P} 1$} & Oi & $0-2$ & 10YR 4/1 & 415.84 & 7.93 & 52 & 6.01 & n.d. \\
\hline & Oea & $2-6$ & 10YR 3/1 & 215.36 & 6.05 & 36 & 6.66 & n.d. \\
\hline & $\mathrm{AE}$ & $6-16$ & 10YR 6/1 & 10.31 & 0.48 & 22 & 5.55 & 99 \\
\hline & $\mathrm{Bs}$ & $16-26$ & 10YR 8/6 & 4.10 & 0.18 & 22 & 4.66 & 97 \\
\hline & $\mathrm{BsC}$ & $26-50$ & 10YR 8/6 & 0.80 & 0.05 & 16 & 4.50 & 94 \\
\hline & $\mathrm{C}$ & $>50$ & 10YR 8/4 & 0.47 & 0.03 & 15 & 4.67 & 99 \\
\hline \multirow[t]{7}{*}{$\mathrm{P} 2$} & Oi & $0-2$ & 10YR 4/1 & 347.18 & 8.85 & 39 & 6.32 & n.d. \\
\hline & Oea & $2-6$ & 10YR 3/1 & 220.03 & 8.50 & 26 & 6.51 & n.d. \\
\hline & $\mathrm{AE}$ & $6-10$ & 10 YR 5/1 & 9.59 & 0.40 & 24 & 5.64 & 99 \\
\hline & $\mathrm{E}$ & $10-16$ & 10 YR 7/1 & 3.52 & 0.17 & 21 & 4.53 & 95 \\
\hline & Bs & $16-36$ & 10 YR 7/6 & 3.64 & 0.17 & 21 & 4.70 & 97 \\
\hline & $\mathrm{BsC}$ & $36-75$ & $2.5 \mathrm{Y} 8 / 6$ & 0.89 & 0.04 & 22 & 4.92 & 96 \\
\hline & $\mathrm{C}$ & $>75$ & 10 YR 8/6 & 0.35 & 0.03 & 11 & 4.76 & 97 \\
\hline \multirow[t]{7}{*}{ P3 } & Oi & $0-3$ & 10YR 4/1 & 339.77 & 7.24 & 46 & 6.95 & n.d. \\
\hline & Oea & $3-8$ & 10YR 3/1 & 188.45 & 6.63 & 28 & 7.34 & n.d. \\
\hline & $\mathrm{AE}$ & $8-13$ & 10YR 5/1 & 19.77 & 0.81 & 24 & 7.09 & 95 \\
\hline & $\mathrm{E}$ & $13-20$ & 10YR 7/1 & 6.93 & 0.26 & 26 & 7.07 & 99 \\
\hline & Bs & $20-40$ & 10YR 7/6 & 4.77 & 0.18 & 26 & 6.75 & 99 \\
\hline & $\mathrm{BsC}$ & $40-70$ & 10YR 8/6 & 1.62 & 0.11 & 15 & 6.20 & 96 \\
\hline & $\mathrm{C}$ & $>70$ & 10YR 8/4 & 1.21 & 0.10 & 12 & 6.03 & 95 \\
\hline \multirow[t]{7}{*}{ P4 } & Oi & $0-4$ & 10YR 4/1 & 321.97 & 7.75 & 41 & 6.77 & n.d. \\
\hline & Oea & $4-10$ & 10YR 3/1 & 225.87 & 6.81 & 33 & 7.06 & n.d. \\
\hline & $\mathrm{AE}$ & $10-15$ & 10YR 5/1 & 7.80 & 0.14 & 35 & 5.34 & 97 \\
\hline & $\mathrm{E}$ & $15-22$ & 10YR 7/1 & 5.43 & 0.20 & 27 & 4.98 & 95 \\
\hline & Bhs & $22-25$ & 10YR 5/4 & 8.35 & 0.40 & 23 & 4.47 & 97 \\
\hline & $\mathrm{BsC}$ & $25-50$ & 10YR 6/6 & 0.73 & 0.05 & 15 & 5.07 & 99 \\
\hline & $\mathrm{C}$ & $>45$ & 10YR 8/6 & 0.86 & 0.10 & 9 & 4.52 & 97 \\
\hline
\end{tabular}

n.d. not determined

\section{Discussion}

Our investigations provide new information on the impacts of deposited alkaline fly ash on Podzol morphology and chemistry. Changes in the soil environment affected by fly ashes emitted by lignite-fired power plants are connected mainly with alkalinisation of ectohumus horizons, where we observed significantly higher concentrations of $\mathrm{NH}_{4} \mathrm{Cl}$ extractable cations and increased base saturation (Klose and Makeshin 2003). However, these impacts may not be limited to soil surface horizons. Our results show that $\mathrm{pH}$ values of Podzol ectohumus horizons located close to a dumping site ranged between 6.01 and 7.34 (Table 2), which is a considerable increase when compared to the control with a range of 3.08-3.72 (Table 1). The alkalisation process was limited to a very short distance. The ectohumus horizon of the profile located $300 \mathrm{~m}$ from the dumping site showed a $\mathrm{pH}$ range from 4.13 to 4.26 , while at a distance of $800 \mathrm{~m}$, the $\mathrm{pH}$ values did not differ from those of the control site (Table 3). Similar studies have shown that in the control profiles the $\mathrm{pH}$ values generally increased with profile depth, which is typical for Podzols (Buurman and Jongmans 2005; Jamroz et al. 2014; Lundström et al. 2000a, b), while soil profiles located at a distance of $50 \mathrm{~m}$ from the dumping site showed a reversed trend. In the deepest horizons (C), the $\mathrm{pH}$ values were lower than in the ectohumus (4.526.46), but still higher than those in the control profiles (4.264.35). This indicates that deposited alkaline fly ash influences whole profiles near the dumping site, while the effect is limited only to the surface soil horizons at a greater distance. The changes in $\mathrm{pH}$ are accompanied by modification of sorption properties of affected soils. Especially, basic cations were dominated by $\mathrm{Ca}^{2+}$, which is typical for fly ash-affected forest soils (Klose and Makeshin 2003).

After such strong changes in soil reaction and sorption properties, the podzolisation processes, regarding the distance from the dumping site, were reduced or even completely ceased. Eluvial soil horizons located close to the dumping site had been transformed into transitional AE horizons in which 
Table 3 The content of TOC and $\mathrm{N}$ and $\mathrm{pH}$ in soil profiles in a transect from $50 \mathrm{~m}$ up to $2 \mathrm{~km}$ from the dumping site

\begin{tabular}{|c|c|c|c|c|c|c|c|}
\hline Profile & $\begin{array}{l}\text { Soil } \\
\text { horizon }\end{array}$ & $\begin{array}{l}\text { Thickness } \\
(\mathrm{cm})\end{array}$ & Colour & $\begin{array}{l}\text { TOC } \\
\left(\mathrm{g} \mathrm{kg}^{-1}\right)\end{array}$ & $\begin{array}{l}\mathrm{N} \\
\left(\mathrm{g} \mathrm{kg}^{-1}\right)\end{array}$ & $\mathrm{C} / \mathrm{N}$ & $\begin{array}{l}\mathrm{pH} \\
(\mathrm{KCl})\end{array}$ \\
\hline \multirow{7}{*}{$\begin{array}{l}\text { PN1 } \\
\qquad \text { (NE } 50 \mathrm{~m})\end{array}$} & Oi & $0-1$ & 10YR 4/1 & 262.34 & 8.84 & 30 & 6.58 \\
\hline & Oea & $1-8$ & 10YR 4/2 & 133.24 & 5.70 & 23 & 6.92 \\
\hline & $\mathrm{AE}$ & $8-14$ & 10YR 5/1 & 9.89 & 0.26 & 37 & 5.63 \\
\hline & $\mathrm{E}$ & $14-24$ & $\begin{array}{l}10 \mathrm{YR} \\
7 / 2.5\end{array}$ & 1.64 & 0.07 & 23 & 4.07 \\
\hline & Bhs & $24-26$ & 10 YR 5/5 & 10.64 & 0.38 & 28 & 5.15 \\
\hline & Bs & $26-50$ & 10YR 6/7 & 2.12 & 0.10 & 21 & 5.84 \\
\hline & $\mathrm{C}$ & $>50$ & 10YR 8/5 & 0.46 & 0.02 & 23 & 6.46 \\
\hline \multirow{5}{*}{$\begin{array}{l}\text { PN2 } \\
\text { (NE } 300 \mathrm{~m})\end{array}$} & Oea & $0-12$ & 10YR 3/1 & 311.47 & 11.62 & 27 & 4.26 \\
\hline & $\mathrm{E}$ & $12-20$ & 10YR 7/1 & 1.51 & 0.10 & 15 & 4.13 \\
\hline & Bhs & $20-25$ & 10YR 5/6 & 12.22 & 0.35 & 35 & 4.01 \\
\hline & Bs & $25-50$ & 10YR 7/6 & 3.30 & 0.13 & 25 & 4.33 \\
\hline & $\mathrm{C}$ & $>50$ & 10YR 8/6 & 0.74 & 0.07 & 10 & 4.41 \\
\hline \multirow{5}{*}{$\begin{array}{l}\text { PN3 } \\
\qquad \text { (NE } 800 \text { m) }\end{array}$} & Oea & $0-9$ & 10YR 3/1 & 182.61 & 8.29 & 22 & 3.31 \\
\hline & $\mathrm{E}$ & 9-20 & 10YR 7/1 & 1.55 & 0.09 & 17 & 3.66 \\
\hline & Bhs & $20-25$ & 10YR 5/6 & 11.73 & 0.33 & 35 & 3.99 \\
\hline & Bs & $25-40$ & 10YR 7/6 & 3.04 & 0.14 & 21 & 4.41 \\
\hline & $\mathrm{C}$ & $>50$ & 10YR 8/4 & 0.70 & 0.07 & 10 & 4.57 \\
\hline \multirow{6}{*}{$\begin{array}{l}\text { PN4 } \\
\qquad \text { (NE } 2000 \text { m) }\end{array}$} & Oie & $0-8$ & $10 \mathrm{YR} 3 / 2$ & 407.58 & 13.96 & 29 & 3.24 \\
\hline & $\mathrm{Oa}$ & $8-22$ & 10YR 3/1 & 138.32 & 5.20 & 27 & 2.41 \\
\hline & $\mathrm{E}$ & $22-32$ & 10YR 7/1 & 3.14 & 0.17 & 18 & 3.44 \\
\hline & Bhs & $32-45$ & 10YR 4/1 & 23.90 & 0.72 & 33 & 2.96 \\
\hline & Bs & $60-90$ & 10YR 6/6 & 3.54 & 0.15 & 23 & 3.82 \\
\hline & $\mathrm{C}$ & $>90$ & 10YR 7/6 & 1.27 & 0.11 & 12 & 4.26 \\
\hline
\end{tabular}

humic substances translocated from the ectohumus horizons were accumulated (Fig. 4). In the P1 profile, even the whole E horizon was transformed into AE. Moreover, organic $\mathrm{C}$ contents in this horizon increased compared to those of the illuvial Bs horizon located below. This indicates that due to alkalisation, greater amounts of organic carbon translocated from the litter horizons directly below, contributing to a new horizon where humic substances are accumulated. This is connected with the higher solubility of humic substances at increased $\mathrm{pH}$ values (Stevenson 1994), which may result in translocation from the litter zone to the upper part of $\mathrm{E}$ horizons. This process would be accelerated by increased organic matter mineralisation (Andersson et al. 2000; Andersson and Nilsson 2001; Lundström et al. 2003a), which is confirmed by the decreased $\mathrm{C} / \mathrm{N}$ ratio of Oea soil horizons located close to the dumping site. These horizons showed $\mathrm{C} / \mathrm{N}$ ratios as low as 25-36, while the corresponding control horizons K1, K2 and $\mathrm{K} 3$ showed $\mathrm{C} / \mathrm{N}$ ratios of $45-51$. In contrast, the $\mathrm{pH}$ value has a well-known effect on soil faunal activity and microbial community composition; under acidic conditions, fungal growth is considerably higher than bacterial growth (Rousk et al. 2009). If organic matter decomposition is mainly dominated by fungi, lower amounts of recalcitrant organic carbon are observed (Heim and Frey 2004). Thus, a drastic increase in soil pH should cause an increase of recalcitrant organic carbon, which is more resistant to decomposition.

Our investigations revealed that under the influence of alkalisation of upper horizons, illuvial Bhs horizons vanished and were transformed into Bs horizons. Bhs soil horizons located close to the dumping site were hardly perceptible, especially in comparison to control profiles. The thickness of this horizon increased along the transect from 2 (PN1 profile) to $13-15 \mathrm{~cm}$ at more distant locations (PN3 and PN4 profiles). The explanation of this process is more complicated and requires further detailed investigations. In a previous study, Catoni et al. (2016) found that the labile and recalcitrant organic pool proportions are linked to the parent material likely through its effect on $\mathrm{pH}$. These authors investigated stable organic carbon in illuvial B horizons from Podzols and observed that most developed soils were comparatively more resilient for organic matter conservation than less developed soils which are more prone to $\mathrm{C}$ losses. The vanishing of the illuvial Bhs horizons may be due to the destroying of organometal complexes, because they are created only at low pH values (Lundström et al. 2000a, b; Buurman and Jongmans 2005) and their stability decreases with increasing pH (Ferro-Vázquez et al. 2014). Increased mineralisation of humic substances and their solubility and 
Table 4 Sorption properties of soil profiles at a distance of $50 \mathrm{~m}$ and $7.3 \mathrm{~km}$ from the dumping site

\begin{tabular}{|c|c|c|c|c|c|c|c|c|c|}
\hline Profile & Horizon & $\begin{array}{l}\mathrm{HA} \\
\mathrm{cmol}\end{array}$ & $\mathrm{Ca}^{++}$ & $\mathrm{Mg}^{++}$ & $\mathrm{K}^{+}$ & $\mathrm{Na}^{+}$ & CEC & $\begin{array}{l}\text { BS } \\
\%\end{array}$ & $\begin{array}{l}\mathrm{Ca}^{++} \text {in } \\
\mathrm{CEC}\end{array}$ \\
\hline \multirow[t]{4}{*}{ P1 } & $\mathrm{AE}$ & 1.20 & 5.00 & 0.57 & 0.30 & 0.04 & 7.11 & 83 & 70 \\
\hline & Bs & 1.04 & 2.30 & 0.41 & 0.17 & 0.03 & 3.95 & 73 & 58 \\
\hline & $\mathrm{BsC}$ & 1.08 & 1.20 & 0.35 & 0.20 & 0.02 & 2.85 & 62 & 42 \\
\hline & $\mathrm{C}$ & 1.04 & 1.20 & 0.42 & 0.14 & 0.02 & 2.82 & 63 & 43 \\
\hline \multirow[t]{5}{*}{ P2 } & $\mathrm{AE}$ & 1.20 & 4.60 & 0.40 & 0.23 & 0.03 & 6.46 & 81 & 71 \\
\hline & $\mathrm{E}$ & 0.88 & 2.00 & 0.32 & 0.17 & 0.02 & 3.39 & 74 & 59 \\
\hline & $\mathrm{Bs}$ & 1.76 & 1.80 & 0.32 & 0.17 & 0.02 & 4.07 & 56 & 44 \\
\hline & $\mathrm{BsC}$ & 0.84 & 1.30 & 0.39 & 0.20 & 0.02 & 2.75 & 69 & 47 \\
\hline & C & 1.04 & 1.00 & 0.28 & 0.14 & 0.02 & 2.48 & 58 & 40 \\
\hline \multirow[t]{4}{*}{ PN1 } & $\mathrm{AE}$ & 2.36 & 8.20 & 0.68 & 0.42 & 0.06 & 13.72 & 82 & 60 \\
\hline & E & 2.28 & 1.80 & 0.42 & 0.23 & 0.04 & 4.77 & 52 & 38 \\
\hline & Bhs & 0.88 & 1.90 & 0.41 & 0.20 & 0.04 & 3.43 & 74 & 55 \\
\hline & $\mathrm{C}$ & 0.68 & 1.40 & 0.38 & 0.19 & 0.03 & 2.68 & 74 & 52 \\
\hline \multirow[t]{5}{*}{ P4 } & $\mathrm{AE}$ & 1.16 & 5.00 & 0.91 & 0.55 & 0.11 & 7.73 & 85 & 65 \\
\hline & $\mathrm{E}$ & 0.44 & 4.50 & 0.44 & 0.23 & 0.02 & 5.63 & 92 & 80 \\
\hline & Bs & 0.88 & 3.50 & 0.37 & 0.23 & 0.31 & 5.29 & 83 & 66 \\
\hline & $\mathrm{BsC}$ & 0.40 & 1.90 & 0.50 & 0.28 & 0.03 & 3.11 & 87 & 61 \\
\hline & $\mathrm{C}$ & 0.40 & 1.20 & 0.37 & 0.28 & 0.03 & 2.28 & 82 & 53 \\
\hline \multirow[t]{5}{*}{ P5 } & $\mathrm{AE}$ & 1.32 & 3.40 & 0.47 & 0.23 & 0.03 & 5.45 & 75 & 62 \\
\hline & $\mathrm{E}$ & 2.16 & 2.10 & 0.43 & 0.23 & 0.04 & 4.96 & 56 & 42 \\
\hline & Bhs & 3.16 & 1.10 & 0.37 & 0.17 & 0.03 & 4.83 & 34 & 23 \\
\hline & $\mathrm{BsC}$ & 0.68 & 1.60 & 0.43 & 0.24 & 0.05 & 3.00 & 77 & 53 \\
\hline & $\mathrm{C}$ & 1.08 & 1.20 & 0.35 & 0.20 & 0.02 & 2.85 & 62 & 42 \\
\hline \multirow[t]{4}{*}{ K1 } & E & 2.96 & 1.00 & 0.43 & 0.21 & 0.03 & 4.63 & 36 & 22 \\
\hline & Bhs & 3.64 & 1.40 & 0.42 & 0.94 & 0.04 & 6.44 & 43 & 22 \\
\hline & Bs & 1.80 & 1.30 & 0.39 & 0.87 & 0.03 & 4.39 & 59 & 30 \\
\hline & $\mathrm{C}$ & 0.56 & 1.80 & 0.37 & 0.80 & 0.02 & 3.55 & 84 & 51 \\
\hline \multirow[t]{4}{*}{ K2 } & $\mathrm{E}$ & 2.88 & 1.00 & 0.38 & 0.17 & 0.03 & 4.46 & 35 & 22 \\
\hline & Bhs & 4.16 & 0.80 & 0.34 & 0.17 & 0.02 & 5.49 & 24 & 15 \\
\hline & Bs & 2.52 & 1.00 & 0.38 & 0.19 & 0.02 & 4.11 & 38 & 24 \\
\hline & C & 0.96 & 0.80 & 0.31 & 0.17 & 0.02 & 2.77 & 65 & 29 \\
\hline \multirow[t]{4}{*}{ K3 } & $\mathrm{E}$ & 3.16 & 1.00 & 0.41 & 0.23 & 0.03 & 4.83 & 34 & 21 \\
\hline & Bhs & 6.92 & 1.90 & 0.48 & 0.23 & 0.07 & 8.90 & 22 & 21 \\
\hline & Bs & 1.44 & 1.80 & 0.31 & 0.83 & 0.03 & 4.51 & 66 & 40 \\
\hline & C & 1.12 & 1.20 & 0.34 & 0.50 & 0.02 & 3.57 & 68 & 34 \\
\hline
\end{tabular}

leaching in response to increased $\mathrm{pH}$ values may also play

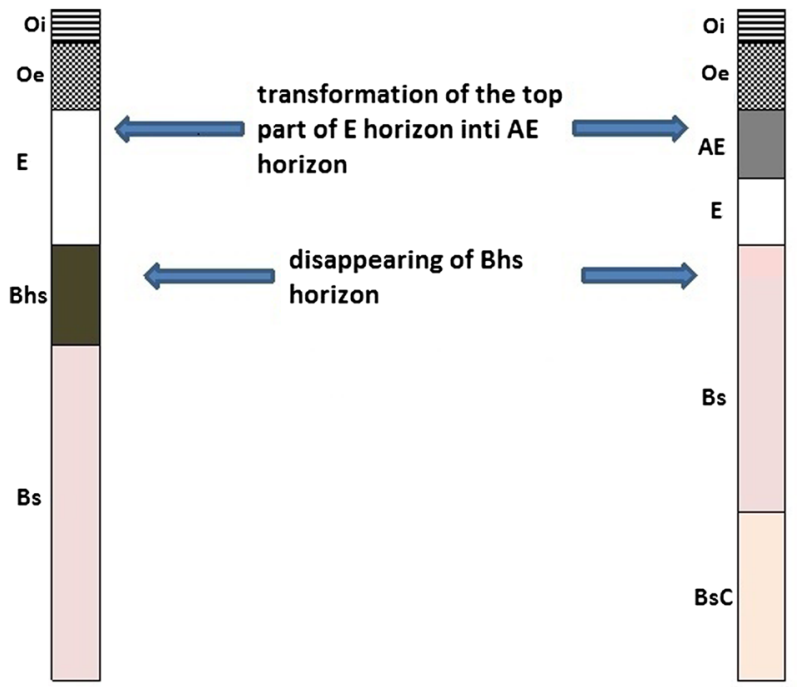

Profile K2

Profile $\mathbf{P 2}$

Fig. 4 Changes in soil morphology under the influence of alkalisation from deposited fly ash a role here (Lundström et al. 2000a, b, 2003b). Finally, the amount of humic substances translocated from $\mathrm{E}$ to spodic $\mathrm{B}$ horizons is lower, because they are likely stabilised and accumulated in AE horizon. This can be confirmed by the ratio of organic carbon content in Bhs horizon to $\mathrm{C}$ content in $\mathrm{E}$ horizon, indicating the intensity of organic components translocation. This ratio ranged from 2.01 to 3.26 in the control profiles and from 0.39 to 1.54 in profiles located $50 \mathrm{~m}$ from the dumping site. Nevertheless, in order to explain the transformation processes of Bhs horizons to Bs horizons, which are much poorer in organic compounds, further research on humic substances is required.

\section{Conclusions}

Changes of the soil environment affected by fly ashes from dumping sites of lignite-fired power plants are connected mainly with alkalinisation of ectohumus horizons. 
Significant changes in $\mathrm{pH}$ and base saturation are limited to a negligible distance from the dumping site, especially if the site is surrounded by forest. However, these impacts may be limited not only to the soil surface horizons. In the case of Podzols, podzolisation processes can be reduced or even completely stopped regarding the distance from the dumping site. Eluvial E horizons of Podzols located close to a dumping site may be transformed to transitional AE horizons in which humic substances translocated from ectohumus horizons are accumulated. Due to $\mathrm{pH}$ neutralisation processes and, consequently, transformation and translocation of organic components, illuvial Bhs horizons can be transformed into Bs horizons. Nevertheless, the explanation of transformation processes of Bhs horizons to Bs horizons, which are much poorer in organic compounds, requires additional advanced research of humic substances.

Open Access This article is distributed under the terms of the Creative Commons Attribution 4.0 International License (http:// creativecommons.org/licenses/by/4.0/), which permits unrestricted use, distribution, and reproduction in any medium, provided you give appropriate credit to the original author(s) and the source, provide a link to the Creative Commons license, and indicate if changes were made.

\section{References}

Aciego Pietri JC, Brookes PC (2008) Relationships between soil pH and microbial properties in a UK arable soil. Soil Biol Biochem 40: 1856-1861

Ahmaruzzaman M (2010) A review on the utilization of fly ash. Prog Energy Combust Sci 36:327-363

Andersson S, Nilsson SI (2001) Influence of $\mathrm{pH}$ and temperature on microbial activity, substrate availability of soil-solution bacteria and leaching of dissolved organic carbon in a mor humus. Soil Biol Biochem 33:1181-1191

Andersson S, Nilsson SI, Saetre P (2000) Leaching of dissolved organic carbon (DOC) and dissolved organic nitrogen (DON) in mor humus as affected by temperature and $\mathrm{pH}$. Soil Biol Biochem 32:1-10

Bain DC, Tau Strand L, Gustafsson JP, Melkerud P-A, Frase AR (2003) Chemistry, mineralogy and morphology of spodosols at two Swedish sites used to assess methods of counteracting acidification. Water Air Soil Poll: Focus 3:29-47

Buurman P, Jongmans AG (2005) Podzolization and soil organic matter dynamics. Geoderma 125:71-83

Catoni M, D'Amico ME, Zanini E, Bonifacio E (2016) Effect of pedogenic processes and formation factors on organic matter stabilization in alpine forest soils. Geoderma 263:151-160

FAO World Reference Base for Soil Resources (2014). World soil resources report no. 106, FAO, Rome

Ferro-Vázquez C, Nóvoa-Muñoz JC, Costa-Casais M, Klaminder J, Martínez-Cortizas A (2014) Metal and organic matter immobilization in temperate podzols: a high resolution study. Geoderma 217218:225-234

Food and Agriculture Organization of the United Nations (2006) Guidelines for soil description. Fourth edition. Food and Agriculture Organization of the United Nations, Rome
Gee G, Bauder JW (1986) Particle-size analysis. In: Klute A (ed) Methods of analysis. Part I agronomy series 9. Am. Soc. Agronomy Soil Sci. Am. Inc. Publ, Madison

Haapala H, Goltsova N, Pitulko V, Lodenius M (1996) The effects of simultaneous large acidic and alkaline airborne pollutants on forest soil. Environ Pollut 94(2):159-168

Haapala H, Goltsova N, Lodenius M (2001) Heavy metals solubility in podzolic soils exposed to the alkalizing effect of air pollutants. Environ Pollut 115:33-41

Hartmann P, Fleige U, Horn R (2010a) Proof of fly ash deposition in forest soils and the effects on soil physical properties. Bodenkultur 61(2):5-17

Hartmann P, Fleige U, Horn R (2010b) Changes in soil physical properties of forest floor horizons due to long-term deposition of lignite fly ash. J Soils Sediments 10(2):231-239

Haynes RJ (2009) Reclamation and revegetation of fly ash disposal sites - challenges and research needs. J Environ Manag 90:43-53

Heim A, Frey B (2004) Early stage litter decomposition rates for Swiss forests. Biogeochem 70:301-315

Jala S, Goyal D (2006) Fly ash as a soil ameliorant for improving crop production - a review. Bioresour Technol 97:1136-1147

Jamroz E, Kocowicz A, Bekier J, Weber J (2014) Properties of soil organic matter in podzols under mountain dwarf pine (Pinus mugo Turra.) and Norway spruce (Picea abies (L.) karst.) in various stages of dieback in the east Sudety Mountains, Poland. For Ecol Manag 330:261-270

Klose S, Makeshin F (2003) Effects of past fly ash deposition on the forest floor humus chemistry of pine stands in northeastern Germany. For Ecol Manag 183:113-126

Klose S, Koch J, Baucker E, Makeschin F (2001) Indicative properties of fly-ash affected forest soils in northeastern Germany. J Plant Nutr Soil Sci 164(5):561-568

Langer U, Gunther T (2001) Effects of alkaline dust deposits from phosphate fertilizer production on microbial biomass and enzyme activities in grassland soils. Environ Pollut 112:321-327

Lundström US, Van Breemen N, Bain D (2000a) The podzolization process. A review. Geoderma 94:91-107

Lundström US, Van Breemen N, Bain DC, Van Hees PAW, Giesler R, Gustafsson JP, Ilvesniemi H, Karltun E, Melkerud P-A, Olsson M, Riise G, Wahlberg O, Bergelin A, Bishop K, Finlay R, Jongmans AG, Magnusson T, Mannerkoski H, Nordgren A, Nyberg L, Starr M, Tau Strand L (2000b) Advances in understanding the podzolization process resulting from a multidisciplinary study of three coniferous forest soils in the Nordic countries. Geoderma 94:335-353

Lundström US, Bain DC, Taylor AFS, Van Hees PAW (2003a) Effects of acidification and its mitigation with lime and wood ash on forest soil processes: a review. Water Air and Soil Pollut: Focus 3:5-28

Lundström US, Bain DC, Taylor AFS, Van Hees PAW, Geibe CE, Holmström SJM, Melkerud P-A, Finlay R, Jones DL, Nyberg L, Gustafsson JP, Riise G, Tau Strand L (2003b) Effects of acidification and its mitigation with lime and wood ash on forest soil processes in southern Sweden. A joint multidisciplinary study. Water Air Soil Pollut: Focus 3:167-188

Mandre M, Ots K (1999) Growth and biomass partitioning of 6-year-old spruces under alkaline dust impact. Water Air Soil Pollut 114:13-25

Mandre M, Kask R, Pikk J, Ots K (2008) Assessment of growth and stemwood quality of scots pine on territory influenced by alkaline industrial dust. Environ Monitor Assess 138:51-63

Ostrowski M (2011) Charakterystyka morfologii popiołów lotnych ze spalania wegli brunatnych. Scientific Works of Institute of Ceramics and Building Materials. Nr 8, Rok IV, 136-150

Ots K (2003) Impact of emission from oil shale fueled power plants on the growth and foliar elemental concentrations of scots pine in Estonia. Environ Monitor Assess 85(3):293-308 
Pichler V, Homolák M, Capuliak J (2009) Long-term soil reaction changes in a temperate beech Forest subject to past alkaline pollution. Water Air Soil Pollut 204:5-18

Raja R, Nayak AK, Shukla AK, Rao KS, Gautam P, Lal B, Tripathi R, Shahid M, Panda BB, Kumar A, Bhattacharyya P, Bardhan G, Gupta S, Patra DK (2015) Impairment of soil health due to fly ash-fugitive dust deposition from coal-fired thermal power plants. Environ Monit Assess 187(11):679

Rousk J, Brookes PC, Bååth E (2009) Contrasting soil pH effects on fungal and bacterial growth suggest functional redundancy in carbon mineralization. Appl Environ Microbiol 75:1589-1596

Stevenson FJ (1994) Humus chemistry, 2nd edn. Wiley, New York

Ukwattage NL, Ranjith PG, Bouazza M (2013) The use of coal combustion fly ash as a soil amendment in agricultural lands (with comments on its potential to improve food security and sequester carbon). Fuel 109:400-408

Van Breemen N, Mudler J, Triscoll CT (1983) Acidification and alkalinization of soil. Plant Soil 75:283-308

Weber J, Strączyńska S, Kocowicz A, Gilewska M, Bogacz A, Gwiżdż M, Debicka M (2015) Properties of soil materials derived from fly ash 11 years after revegetation of post-mining excavation. Catena 133:250-254

Yao ZT, Ji XS, Sarker PK, Tang JH, Ge LO, Xia MS, Xi YO (2014) Comprehensive review on the application of coal fly ash. Earth Sci Rev 141:105-121

Żolnierz L, Weber J, Gilewska M, Strączyńska S, Pruchniewicz D (2016) The spontaneous development of understory vegetation on reclaimed and afforested post-mine excavation filled with fly ash. Catena 136:84-90 